\title{
電子デバイスの導電性樹脂による実装プロセスの検討
}

\section{Study for Electric Device Assembly Process Using Conductive Adhesive}

藤 野 純 司*

Junji FUJINO

(Received May 19, 2005)

\begin{abstract}
Electric devices with semiconductors are applied to all apparatus including substation equipment, transport machines, home electronics, and cellular phones. Power modules deal large current, and high frequency/optical modules control GHz band signals. As a result, these semiconductors have more than 100 times heat density of memory or MPU chips. Pb-rich high temperature solder and expensive Au-rich solder are applied to these modules, however, thermal stress might be a problem not only for long-term reliability but also for the initial characteristics.

The authors studied the assembly of these electric devices using conductive adhesive as a substitute bonding material. We proved that atmospheric aluminum oxides caused electric resistance and that power chips with long rectangle sides over 10 $\mathrm{mm}$ have a much larger thermal resistance than theoretical values. We found that it is effective to scratch and remove these oxides through transferred adhesive on aluminum electrodes and to diebond them onto the solder projection previously formed on the die pads.
\end{abstract}

Key Words: Power Module, Optical Module, Conductive Adhesive, Electric Resistance, Thermal Resistance

\section{1. 緒言}

輸送機器や変電所システムなどの大型設備から, 携帯情報 端末や家電製品などの小型製品まで, 現代の生活のあらゆる 場面で半導体素子を用いた電子デバイスが適用されている。 特に近年の環境問題から, 分散発電システムや輸送機器の省 エネルギーを実現するパワーモジュールの適用範囲は広がり つつある。また，ブロードバンドネットワークや高品位デジ タル放送の普及に伴い，高周波/光モジュールはさらなる高 速動作と高出力化が求められている。これら電子デバイスで 用いられるパワー素子は数千 A におよぶ大電流を制御する ため，また高周波/光素子は数十 $\mathrm{GHz}$ の高周波信号を微小素 子で制御するため，一般的なメモリ一やMPU 用半導体素子 の 100 倍以上の発熱密度を有する。

パワーモジュールの概念図を Fig.1 に示す1)。熱伝導に優 れたセラミックベースの基板に, 複数個のパワー素子がダイ ボンディングされ, 最大 1000 ポイントにも及ぶ $\mathrm{Al}$ ワイヤボ ンディングによって電気的接続が形成される。このセラミッ ク基板がさらに金属製の放熱板に搭載され，ケースごと絶縁 用のゲルなどで封止されてデバイス実装される。このパワー 素子のダイボンディングには, 温度差をつけたステップはん だ付の必要から，Pb を多く含んだ高融点はんだが使用され ることが多い。
高周波/光モジュールの概念図を Fig.2 に示す。高周波/光 素子が搭載された金属やセラミック製のヒートスプレッダが

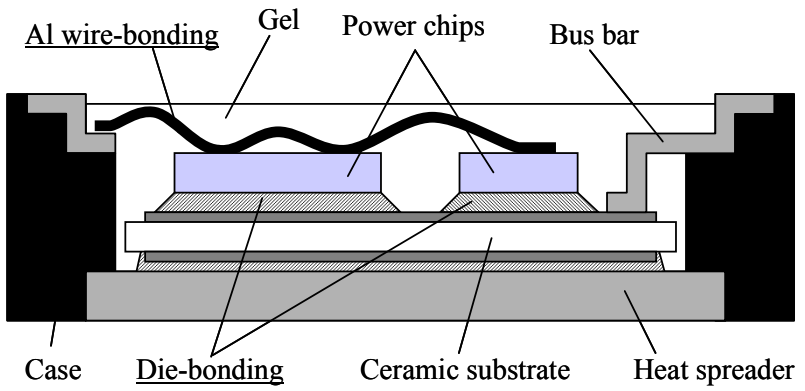

Fig.1 Power module.

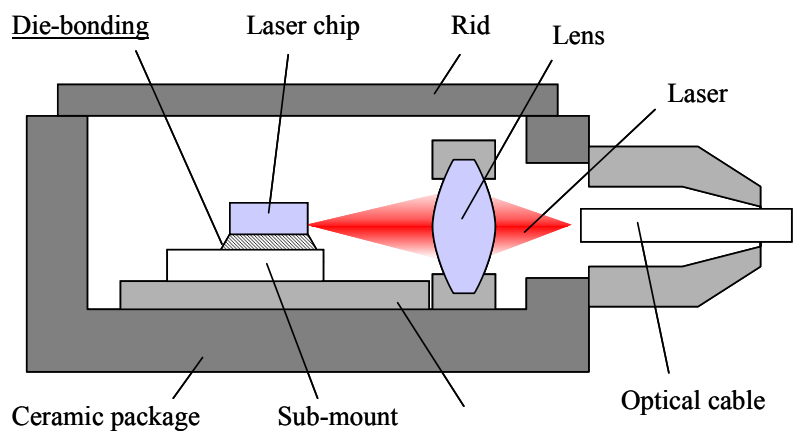

Fig.2 Optical module.

*三菱電機株式会社 高周波・光デバイス製作所 (テ664-8641 兵庫県伊丹市瑞原 4 丁目 1 番地)

Mitsubishi Electric Corp.-High Frequency \& Optical Device Works. (4-1 Mizuhara Itami, Hyogo 664-8641, Japan) 
パッケージにダイボンディングされ，Au ワイヤや $\mathrm{Au}$ リボ ンなどで電気的に接続される。これらのモジュールの多くは, キャップなどで気密封止されてデバイス実装される。この高 周波/光素子のダイボンディングには，気密封止や光学系の 污染を防止するためにフラックスレスはんだ付の必要から， 80Au20Sn はんだが使用されることが多い。

Al ワイヤボンディングは，接合不良があると電気抵抗が 大きくなってジュール熱が増大し，素子を損傷する可能性が ある2)。また， $\mathrm{Pb}$ を多く含んだはんだは，85\%以上の含有率 のものについては現時点では規制対象外であるが, 環境問題 の点からも使用しないことが望ましい。さらに，80Au20Sn はんだは，コスト面や貴金属の消費を防ぐためにも使用を制 約する必要がある。

本研究では，Al ワイヤボンディングやはんだダイボンデ イングの代替接合材料として, Ag フィラーを樹脂に分散さ せた導電性接着剂を取り上げ, その適用性について検討した。

\section{2. 高放熱デバイス実装に要求される特性}

発熱密度の大きな半導体素子のデバイス実装においては, 半導体素子で発生する熱を可能な限り低減し, 基板や放熱板 に放熱することが重要となる。

半導体素子において発生する熱の一部であるジュール熱を 低減するためには, 接合界面の電気抵抗が小さいことが望ま しい。

また，放熱性を向上させるには，ダイボンディング部の熱 抵抗を低減することが必要となる。ダイボンディング部の熱 抵抗は，接合部に発生するボイド（空隙）によっても増大す るため，ボイドの少ない接合部の形成が必要となる。

さらに初期特性だけでなく, 長期信頼性の面から特性が経 時劣化しないことが求められる。パワー素子や高周波/光素 子で用いられるウエハ材料である $\mathrm{Si}$ や $\mathrm{GaAs}$ は, 線熱膨張係 数が $3 \sim 5 \times 10^{-6} \mathrm{~m} / \mathrm{mK}$ 程度であるのに対し, アルミナ製や $\mathrm{AlN}$ 製セラミック基板は 7 $8 \times 10^{-6} \mathrm{~m} / \mathrm{mK}$ とやや大きく，放熱板 としてよく用いられる $\mathrm{Cu}$ は $17 \times 10^{-6} \mathrm{~m} / \mathrm{mK}$ であり， $\mathrm{Al}$ は 23 $\times 10^{-6} \mathrm{~m} / \mathrm{mK}$ とさらに大きい。このことが原因で界面の剥離 やクラックが進展し, 電気抵抗や熱抵抗が大きくなることは 避けなければならない。特に高周波/光素子は，熱応力によ る結晶の歪によって最高出力やしきい值電流などの特性にも 影響を受けやす(3)4) 5)。上記の理由から，接合部の熱応力は 可能な限り小さくする必要があり，はんだと比較すると低温 接合プロセスであり, 弾性係数の低い導電性接着剤は, これ らの問題点を解決できる可能性を有する ${ }^{6)}$ 。

\section{3. 供試材料および実験方法}

\section{1 供試材料}

今回用いた導電性接着剤は市販の $\mathrm{Ag}$ ペーストで，エポキ シ系樹脂に直径 $0.01 \mathrm{~mm}$ 程度の鱗片状 $\mathrm{Ag}$ フィラーと $0.001 \mathrm{~mm}$ 径程度の球形 $\mathrm{Ag}$ 粒を分散させたものである。接合部の断面 図を Fig.3 に示す。電気抵抗と熱抵抗の低減を目的に, $\mathrm{Ag}$
含有率は $90 \mathrm{wt} \%$ 程度と極めて多くなっている。実験に用い た市販接着剤の物性值（メーカ測定カタログ值）を Table 1 に 63Sn-37Pb はんだと比較して示す。体積抵抗率で比較する と, $63 \mathrm{Sn}-37 \mathrm{~Pb}$ はんだが $5 \times 10^{-8} \Omega \mathrm{m}$ であるのに対して, 導電 性接着剤は $4 \sim 5 \times 10^{-7} \Omega \mathrm{m}$ と約 10 倍に高くなっている。ま た，熱伝導率は $\mathrm{Sn}-\mathrm{Pb}$ 系はんだが $38 \mathrm{~W} / \mathrm{mK}$ であるのに対し て, 導電性接着剤は $15 \sim 25 \mathrm{~W} / \mathrm{mK}$ と約 $1 / 2$ 倍に低くなってい る。

被接合材料としては $20 \mathrm{~mm} \times 30 \mathrm{~mm} \times 1 \mathrm{~mm}$ の $\mathrm{Al}$ 板, $\mathrm{Cu}$ 板, および $\mathrm{Cu}$ めっき $\mathrm{Al}$ 板を用意した。また 5 種類のサイズの $\mathrm{Si}$ 製ダイオード素子(1) $4.0 \mathrm{~mm} \times 3.0 \mathrm{~mm}$ ，(2) $7.0 \mathrm{~mm} \times 5.0 \mathrm{~mm}$, (3) $10.0 \mathrm{~mm} \times 5.0 \mathrm{~mm}$, (4) $11.0 \mathrm{~mm} \times 6.0 \mathrm{~mm}$, (5) $16.0 \mathrm{~mm} \times 10.0 \mathrm{~mm}$ を用意した。

3.2 電気抵抗測定用サンプルの作製と電気抵抗の測定方法 3.2.1 サンプル作製方法

導電性接着剤 $\mathrm{A}$ を用い, 転写供給用として直径 $5 \mathrm{~mm}$ のア ルミ製転写ピンを用いた。厚さ $0.1 \mathrm{~mm}$ の深さを有する転写 ステージに，導電性接着剤をスキージングし，転写ピンを用 いて $\mathrm{Al}$ 板上に供給を行った。長手方向に $10 \mathrm{~mm}$ ずらした位 置に $\mathrm{Cu}$ 板を搭載し， $50 \mathrm{~g}$ の分銅を用いて荷重をかけながら $170^{\circ} \mathrm{C}$ に設定したホットプレートにて $3600 \mathrm{~s}$ キュアすること でサンプル作製を行った。断面の観察結果から，約 $0.1 \mathrm{~mm}$ の厚さの接合部が形成され, その直径は約 $10 \mathrm{~mm}$ となること が分かった。

\subsection{2 電気抵抗測定方法}

四端子法電気抵抗測定器を用い, $\mathrm{Al}$ 板と $\mathrm{Cu}$ 板に端子を接 触させて電気抵抗の測定を行った。なお，測定值のばらつき を吸収するために 3 回の測定の平均值を抵抗值として採用す ることとした。また，比較のため, $\mathrm{Cu}$ 板- $\mathrm{Cu}$ 板の場合の測

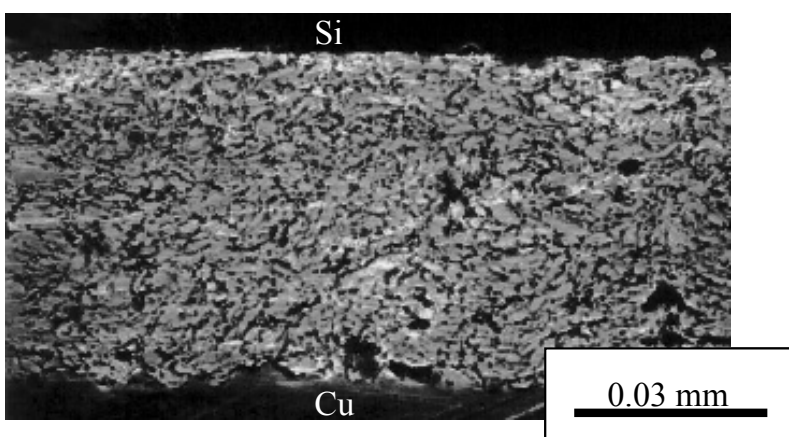

Fig.3 Crosssection of conductive adhesive.

Table 1 Material properties of conductive adhesive.

\begin{tabular}{c||c|c|c|c|c}
\hline Material & $\begin{array}{l}\mathrm{Tg} \\
\left({ }^{\circ} \mathrm{C}\right)\end{array}$ & $\begin{array}{l}\text { Thermal } \\
\text { conductivity } \\
(\mathrm{W} / \mathrm{m} \cdot \mathrm{K})\end{array}$ & $\begin{array}{l}\text { Volume } \\
\text { resistance } \\
(\Omega \mathrm{m})\end{array}$ & $\begin{array}{l}\text { Young's } \\
\text { modulus } \\
(\mathrm{MPa})\end{array}$ & $\begin{array}{l}\mathrm{Ag} \\
\text { contents } \\
(\mathrm{wt} \%)\end{array}$ \\
\hline Adhesive A & 40 & 25 & $4 \times 10^{-7}$ & 1240 & 90 \\
\hline Adhesive B & 15 & 15 & $5 \times 10^{-7}$ & 570 & $88 \sim 90$ \\
\hline $63 \mathrm{Sn}-37 \mathrm{~Pb}$ & - & 38 & $5 \times 10^{-8}$ & 21600 & - \\
\hline
\end{tabular}


定も行った。

\section{3 熱抵抗測定用サンプルの作製と熱抵抗の測定方法}

\section{3.1 サンプル作製方法}

半導体素子など角型形状への導電性接着剤の供給方法とし ては, 開ロマスク印刷, メッシュマスク印刷, 転写, ディス ペンサ供給が考えられるが, ディスペンサ供給で用いるシリ ンジ内にペーストを充填すると, フィラーと樹脂成分の分離 が進行するため 86400s（1day）以内に使い切る必要があるこ とから評価対象から除外した。

残りの 3 手法についてガラスチップを用い, 接合後のボイ ド観察を行った。導電性接着剤 $\mathrm{B}$ の標準的な加熱プロファ イル（昇温速度 $0.17^{\circ} \mathrm{C} / \mathrm{s}$ で $85^{\circ} \mathrm{C}$ ま゙加熱して $1800 \mathrm{~s}$ 保持。そ の後昇温速度 $0.17^{\circ} \mathrm{C} / \mathrm{s}$ で $175^{\circ} \mathrm{C}$ ま加熱して $900 \mathrm{~s}$ 保持。荷重 は $0.01 \mathrm{MPa}_{\circ}$ ) にてキュアを行った。ガラスチップ側から接 合部をスキャナーで画像取り込みを行い, デジタル処理によ つて 2 值化した結果, Fig.4 に示すように, 開ロマスクやメ ッシュマスクでは, $20 \%$ 以上のボイド率となっている。これ はマスクの版離れ後の表面凹凸が起因と推定される。一方, 直径 $5 \mathrm{~mm}$ の転写ピンを用いた転写手法では, ボイド率が $0.5 \%$ に抑制されていることが分かった。

パワーモジュールでは最大で $15 \mathrm{~mm} \square$ 程度のパワー素子を 用いる場合がある。このような大面積ダイボンディング部に おいて 1 箇所に集中して供給すると, 導電性接着剤が広がっ たときの形状が円形となり, 長方形の素子でははみ出しを生 じる。四角形状に 4 箇所に供給すると, 中央部に取り残され る空間ができてしまうために，Fig.5 に示すようにボイドが できやすくなる。一方，中央を $5 \mathrm{~mm}$ 径，周囲 4 点を $3 \mathrm{~mm}$ 径 とした 5 点供給によってほぼボイド発生が抑制されることが 確認された。

開ロマスク,メッシュマスクともパワー素子表面への印刷 を考えた場合, 素子表面へのダメージを防止するために高コ ストなマスクの鏡面処理が必要である。一方で，転写法では 転写ステージに残ったペーストを回収でき, 高価な導電性接 着剂の使用量を必要最小限に抑制することが可能である。こ れらのことから, 以降は導電性接着剤の供給方式としては転 写法を採用した。

各サイズのダイオード素子に合わせた転写ピンを用意し， 導電性接着剤 B を供給し， $\mathrm{Cu}$ 放熱板上にダイオード素子を 搭載して, $0.01 \mathrm{Mpa}$ の荷重をかけながらホットプレートにて $170^{\circ} \mathrm{C} 3600 \mathrm{~s}$ のキュアを行った。さらに $\mathrm{Cu}$ 放熱板上に $3 \mathrm{~mm}$ $\times 20 \mathrm{~mm} \times 1 \mathrm{~mm}$ の $\mathrm{Al}$ 端子を耐熱両面テープで絶縁しながら 接着し, ダイオード表面と $\mathrm{Al}$ ワイヤボンディングによって 接続してサンプル作製を行った。

\section{3. 2 熱抵抗測定方法}

Fig.6 に示すように, ダイオード表面と $\mathrm{Cu}$ 放熱板裏面に形 成した溝に $\phi 0.05 \mathrm{~mm}$ の熱電対を耐熱テープを用いて固定し, アルミ製放熱フィンに $\mathrm{Cu}$ 放熱板を熱伝導グリスによって接

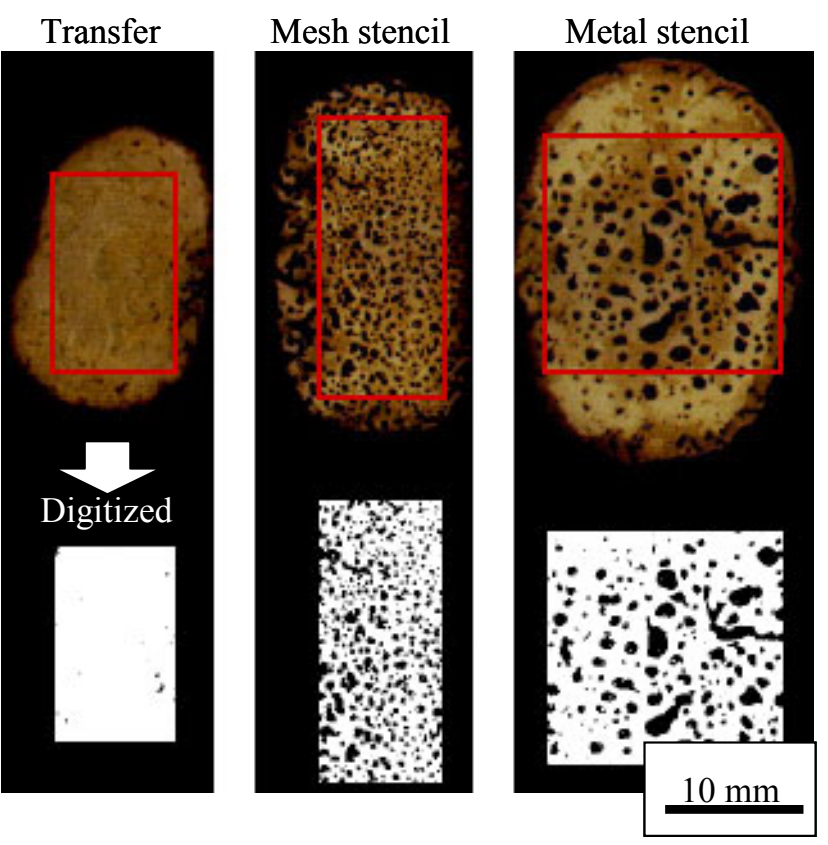

Fig.4 Supplying methods and voids.

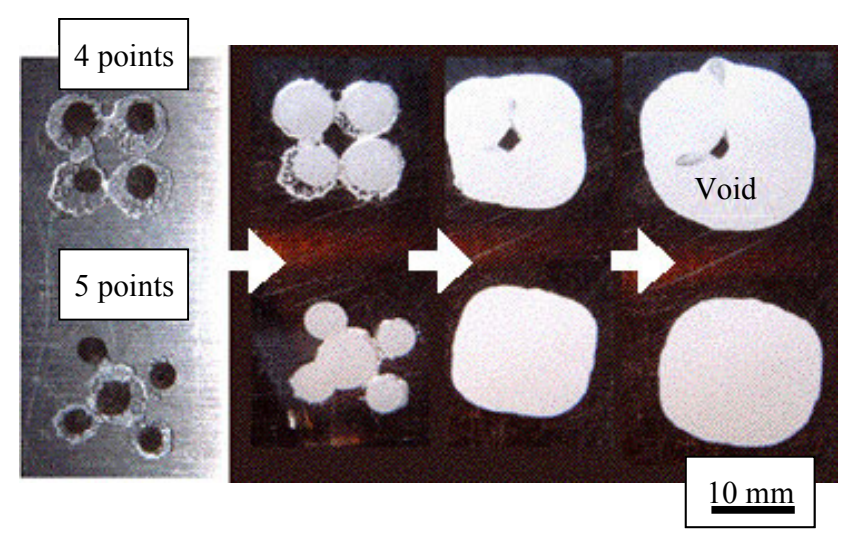

Fig.5 Supplying points and voids.

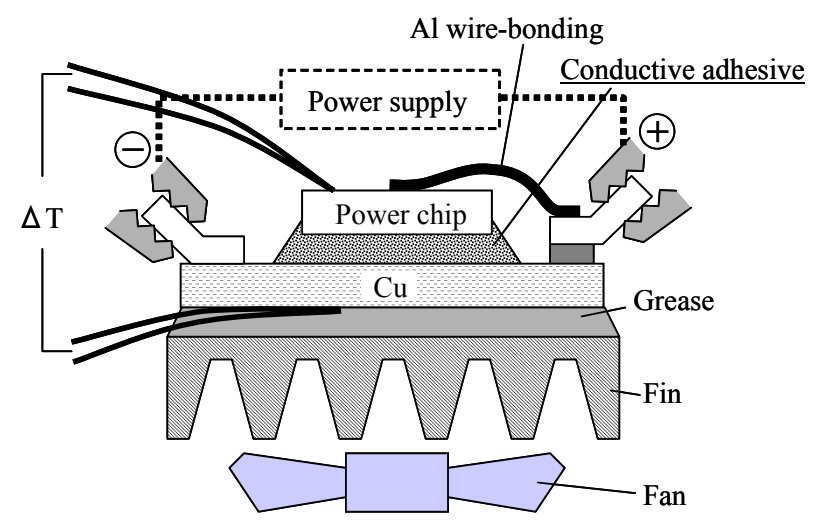

Fig.6 Thermal resistance measuring method.

触させた。放熱フィンはファンを用いて十分冷却し, ダイオ 一ドに所定の電圧をかけ, 通電すると素子上面と $\mathrm{Cu}$ 板下面 との間に温度差 $(\Delta \mathrm{T})$ を生じる。その温度差を, 電流值 $(\mathrm{A})$ と電圧 $(\mathrm{V})$ の積で除すると熱抵抗值 $(\mathrm{K} / \mathrm{W})$ が求められる。 
なお，温度差を測定する場合，フィンへの接触状態によって 測定值に士 $10 \%$ 程度のばらつきが生じるため, 接触状態を変 えながら 10 回繰り返し測定し, 平均值を求めることとした。

\section{4. 導電性樹脂によるダイボンディング部の電気抵抗}

\section{1 ダイボンディング部の電気抵抗計測結果}

$\mathrm{Cu}$ 板 $-\mathrm{Cu}$ 板で金属板の端部間の電気抵抗を測定すると, 安定して $0.15 \mathrm{~m} \Omega$ 前後を示すのに対し, $\mathrm{Al}$ 板 $-\mathrm{Cu}$ 板では $1 \mathrm{~m}$ $\Omega$ から数十 $\mathrm{m} \Omega$ と抵抗值が大きくなり，ばらつきも大きいこ とが分かった。これは，Al 板の表面には緻密な自然酸化膜 が生成されており, $\mathrm{Ag}$ フィラーの接触点での電気抵抗とな っていると考えられる7) 8 )

なお，これらの数值から逆算すると， $\mathrm{Cu}$ 板 $-\mathrm{Cu}$ 板の場合 でも導電性接着剤の体積抵抗率は $10^{-5} \Omega \mathrm{m}$ オーダとなり，力 タログ值よりも 100 倍以上大きい。これは界面抵抗を含むた めで，金属板表面の酸化状態だけでなく，金属板表面と $\mathrm{Ag}$ フィラーの接触状態によっても左右されるものと考えられる。

\section{2 電極表面のスクラッチによる電気抵抗改善}

前項で示した電気抵抗の測定結果からわかるように, $\mathrm{Cu}$ 板および $\mathrm{Al}$ 板に対する接合部では，金属板の表面酸化膜の 影響で電気抵抗が非常に高くなっている。特に $\mathrm{Al}$ 板の表面 酸化膜を除去することにより, 電気抵抗の改善が図られると の考えから，Fig.7 に示すように，金属板上に転写した導電 性接着剤の上からスクラッチ寸ることにより金属板表面の酸 化膜を除去する手法を検討した。スクラッチには，半導体素 子のファンクションテスト用コンタクトプローブ $(0.3 \mathrm{~mm}$ ピ ッチで並んだ 20 本の金属針）を用いた。

スクラッチした金属板表面には，金属針 1 本あたり約 $0.01 \mathrm{~mm} \times 0.02 \mathrm{~mm}$ の圧痕が形成されるが，摩擦によって露出 された金属の新生面が大気に触れにくいために, 再酸化を抑 制することが可能と考えられる。

金属板表面のスクラッチにおいて, Fig.8 に示すように, $\mathrm{A} 1$ 板- $\mathrm{Cu}$ 板の場合にはスクラッチ回数を増すほどに電気抵抗 が小さくなり, 繰り返し測定精度も向上することが分かった。 導電性接着剂供給前にスクラッチを行った場合は, $1.6 \mathrm{~m} \Omega \sim$ $7.3 \mathrm{~m} \Omega$ となり，電気抵抗の改善は確認できなかった。一方， $\mathrm{Cu}$ 板 $-\mathrm{Cu}$ 板の場合には, スクラッチによる電気抵抗の改善 は測定できなかった。

上記の結果から, $\mathrm{Cu}$ と異なり $\mathrm{Al}$ の場合には，数分でも大 気曝露されると $\mathrm{Al}$ の自然酸化膜が生成されて電気抵抗が増 大するが, 金属板上に転写した導電性接着剤の上からコンタ クトプローブを用いてスクラッチ寸ることにより, 再酸化を 抑制できることが確認された。

次に温度サイクル試験 $\quad\left(-40^{\circ} \mathrm{C} \sim+125^{\circ} \mathrm{C} ， 900 \mathrm{~s} / 900 \mathrm{~s}\right)$ を行 った結果，Fig.9 に示すように，Al 板-Cu 板では, サイクル 数に伴い電気抵抗が増大し, その程度はスクラッチ回数の少 ないものほど顕著であることが分かった。20回（400 点）の スクラッチ試験片においては $30 \%$ 程度の電気抵抗増大が確

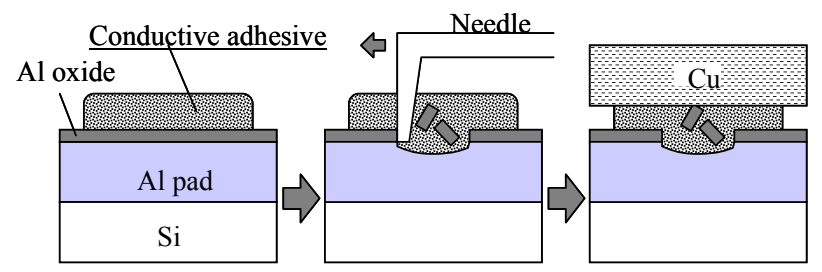

Fig.7 Scratching process.

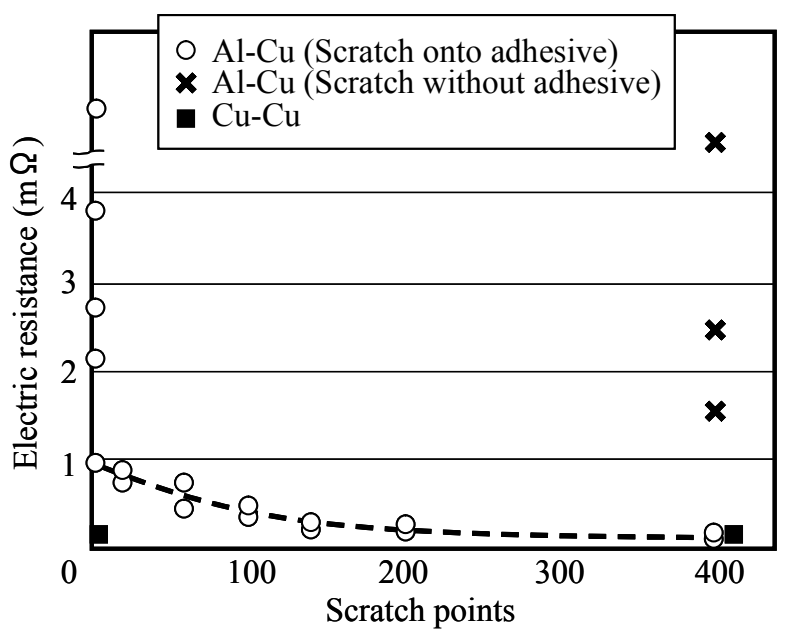

Fig.8 Effect of scratching.

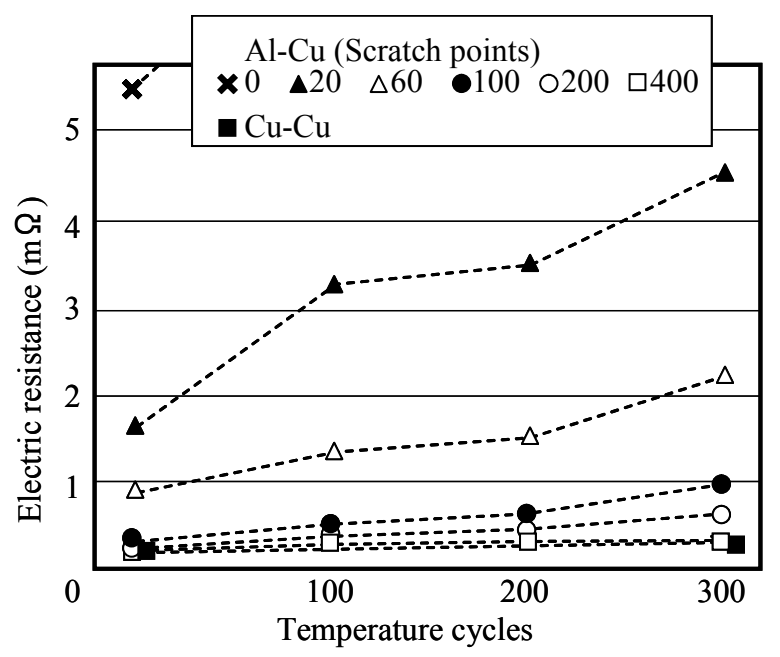

Fig.9 Thermal cycling test.

認された。一方, $\mathrm{Cu}$ 板- $\mathrm{Cu}$ 板試験片は電気抵抗の変化がほ とんどなかった。

実際には $\mathrm{A} 1$ 板- $\mathrm{Cu}$ 板の場合には線熱膨張係数の差があり, $\mathrm{Cu}$ 板 $-\mathrm{Cu}$ 板の場合との単純な比較はできない。線熱膨張係 数の差による熱応力の影響を排除するために, $\mathrm{Cu}$ めっきを 施した $\mathrm{Al}$ 板と $\mathrm{Cu}$ 板を接着し, 同様の温度サイクル試験を 行ったところ, 温度サイクルによる電気抵抗の増大はやはり 約 30\%あり，めっきなし $\mathrm{Al}$ 板-Cu板の場合と同程度であっ た。これらのことから 20 回のスクラッチは十分に $\mathrm{Al}$ の表面 酸化膜の影響を改善できているものと推察される。 


\section{5. 導電性接着剂の熱抵抗}

\section{1 ダイボンディング部の熱抵抗測定結果}

導電性接着剤を用いたサンプルにおいて測定された熱抵抗 值は，物性值から求めた理論值に対して 120〜140\%程度と なった。比較のために導電性接着剂と同じ接合部厚さ（約 $0.03 \mathrm{~mm}$ ）になるように $63 \mathrm{Sn}-37 \mathrm{~Pb}$ はんだを用いて接合し， 同様の測定を行うと熱抵抗值はばらつきも小さく, ほぼ理論 值で安定することが分かった。この差異は，はんだ接合が金 属拡散を伴った接合であるのに比較して，導電性接着剂は $\mathrm{Ag}$ フィラーの接触によって熱伝達を行っているためである と考えられる ${ }^{9)}$ 。従って導電性接着剤の接合メカニズムを含 めて接合部の熱抵抗を論じる必要がある。

(1) $4.0 \mathrm{~mm} \times 3.0 \mathrm{~mm}$ のダイオードの場合，中心からの距離 $2 \mathrm{~mm}$ について線熱膨張係数差とキュア温度から常温までの 温度差 $(150 \mathrm{~K})$ を掛け合わせると最大収縮量の差は $0.004 \mathrm{~mm}$ 程度となる。実際には反りによって伸びの差は緩和され，す べてが剪断に寄与するわけではないが, 素子の長辺が $10.0 \mathrm{~mm}$ となると伸びの差は $0.01 \mathrm{~mm}$ となり，導電性接着剤に含まれ る $\mathrm{Ag}$ フィラーの最大サイズに近くなる。そのためフィラー 同士の接触状態にも大きな恋化が生じると想像される。

素子サイズの影響を検証する目的で，その他の 4 種類のサ イズのダイオードについても同様のダイボンディングを行っ た。(3) $10.0 \mathrm{~mm} \times 5.0 \mathrm{~mm}$ までの範囲では，測定された熱抵抗 值は理論值の $150 \%$ 程度であったが，素子サイズの拡大に伴 って理論值との差異が大きくなり，(4) $16.0 \mathrm{~mm} \times 10.0 \mathrm{~mm}$ 素子 では理論值の $400 \%$ 前後にまで及んだ。

\section{2 温度サイクル試験による熱抵抗増大}

各サイズのダイオード素子をダイボンディングしたサンプ ルを, $-40^{\circ} \mathrm{C} \sim+125^{\circ} \mathrm{C}, 900 \mathrm{~s} / 900 \mathrm{~s}$ の温度サイクル試験にかけ， 100 サイクルごとに 300 サイクルまで熱抵抗值の測定を行っ た。温度サイクル試験後の熱抵抗測定を行うと，Fig.10に示 すように, 素子サイズが大きいほど温度サイクルによる熱抵 抗の増大量も大きくなる。熱抵抗の絶対值ではなく，“300 サイクルにおいて初期熱抵抗值の $130 \%$ までを良品とする“と いう筆者らの温度サイクル良否判定基準に当てはめると, (3) $10.0 \mathrm{~mm} \times 5.0 \mathrm{~mm}$ までが今回用いた導電性接着剤 B でダイボ ンディング可能な最大素子サイズと判断された。

\section{3 はんだとの組み合わせによる熱抵抗改善}

$10 \mathrm{~mm}$ を越えるサイズの素子に導電性接着剤を適用するた めに, 線熱膨張係数差による熱歪みを分散させる手法につい て検討した。Fig.11のように，ソルダレジストの代わりに耐 熱粘着テープを貼った $\mathrm{Cu}$ 板上に，はんだを印刷供給してリ フローし, 洗浄した後, 素子の接着を行う。はんだ印刷量は, はんだ高さが最終的に約 $0.1 \mathrm{~mm}$ となるように調節している。 この方法では, $\mathrm{Cu}$ 板上のはんだが凸面形状を有するために, 熱歪みが大きくなりやすい素子外周部では接着剤厚さが大き
く，発熱が大きい素子中央部では接着剤厚さが小さい。 試験片を作製し，熱抵抗值を測定すると，Fig.12 に示すよ うに，初期值は理論值の $160 \%$ 程度であった。300 サイクル の温度サイクル試験後においても, 熱抵抗值は理論值の $200 \%$ 以下となり，温度サイクルによる熱抵抗の変化は $25 \%$ であ ったことから，筆者らの良品判定では良品とみなすことがで きた。一方, 荷重を少なくして, 導電性接着剤のみを使用し, 接合部厚さが $0.1 \mathrm{~mm}$ となるようにサンプルを作製すると， $\mathrm{Ag}$ フィラー間の接触が不十分なため, その熱抵抗值は初期 值で理論值の $800 \%$ 程度まで大きくなる。

なお，導電性接着剤の $\mathrm{Ag}$ フィラーは $\mathrm{Sn}$ との界面で，局 部電池効果によるボイドが発生して接合強度劣化を生じると

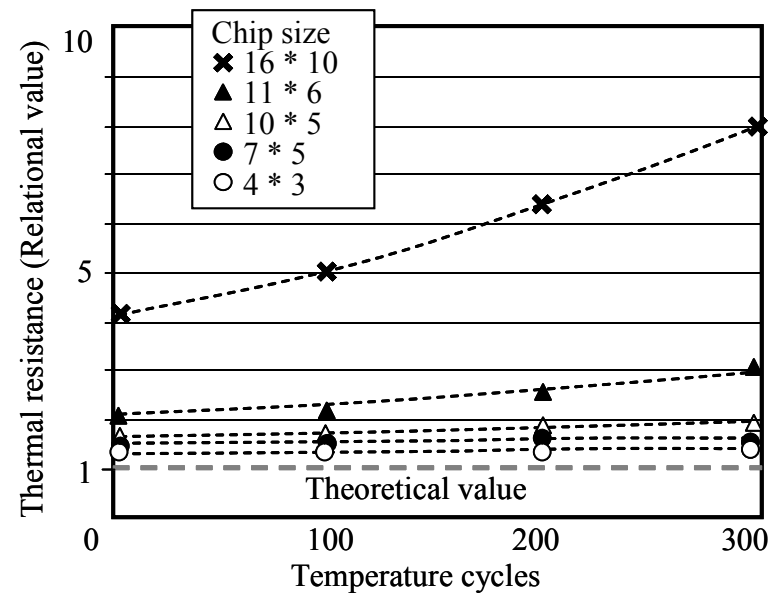

Fig.10 Chip size effect of thermal resistance.

\section{Conductive adhesive}

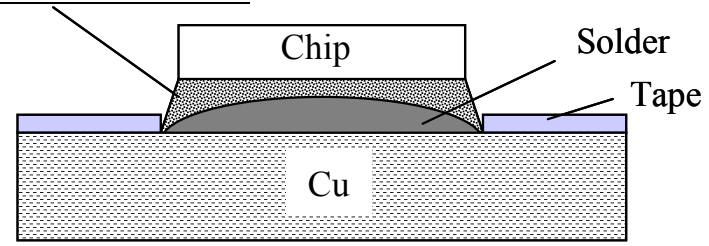

Fig.11 Die-bonding onto solder.

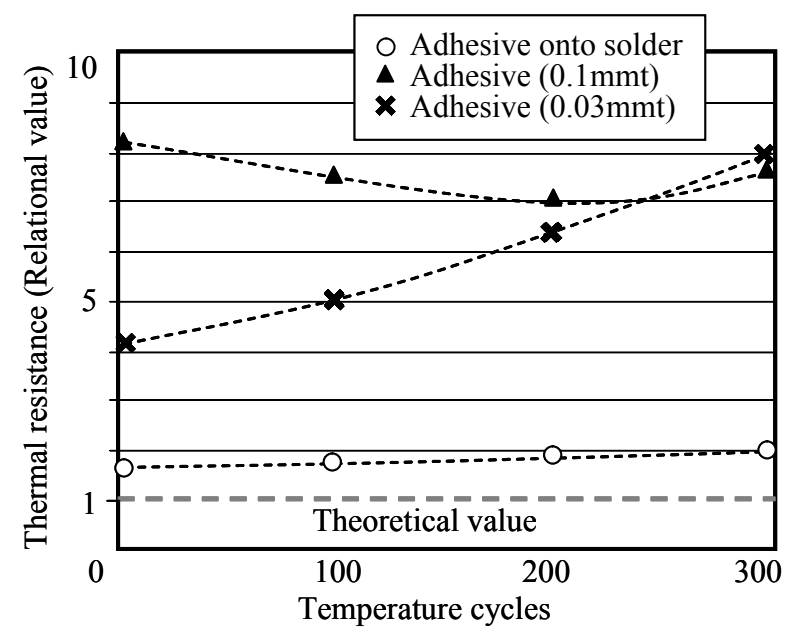

Fig.12 Effect of new die-bonding process. 
の報告があるが，防湿コート等により水分を遮断することで 防止することが可能との報告もある10)。パワーモジュールや 高周波/光モジュールの多くはゲル封止や気密封止されてお り，雾囲気などに留意寸れば十分に適用可能と考えられる。

\section{6. 結言}

本報では, 導電性接着剤の電子デバイスへの適用検討を行 い，以下のような知見を得た。

(1) $\mathrm{Al}$ の自然酸化膜が導電性接着剂による接合部の電気抵 抗を大きくする要因となっている。

（2）導電性接着剂を供給した上から金属針を用いて $\mathrm{Al}$ 表面 を摩擦することで，再酸化を防止しながら $\mathrm{Al}$ 自然酸化膜の 除去が可能である。この方法を用いて $\mathrm{Al}$ 板を $\mathrm{Cu}$ 板と接着 すると, $\mathrm{Cu}$ 板- $\mathrm{Cu}$ 板の場合と同等の電気抵抗に抑えること が可能である。

（3）本報で用いた導電性接着剤の場合， $10 \mathrm{~mm}$ までのパワー 素子では, ダイボンディング部の熱抵抗の測定值は理論值の 150\%程度となるが，これははんだ接合のような金属接合界 面よりも, 導電性接着郕では大きな界面抵抗が存在するため である。

（4） Cu 板に供給した凸面状のはんだ上に接着することで, 16mmサイズの素子においても耐温度サイクル性に優れたダ イボンディングが可能となる。

\section{引用 文 献}

1）加柴良裕: “銅導体セラミック基板,” エレクトロニクス実装技 術, 6 (1991) 71-74.

2) 大貫仁, 小泉正博, 二瓶正恭: "パワー半導体におけるワイヤボン ディング技術," 第 52 回マイクロ接合研究委員会 (1997) 25-38.

3) 伊藤良一，中村道治: "半導体レーザ," (1989) 183.

4) Daisuke UEDA: "Recent Aspects of GaAs Devices for Mobile Communication System," MWE'97 Microwave Workshop Digest, (1997) 143-148

5) K. ATSUMI: " Highly Reliable High Power Diode Laser for Laser Radar Application,” Denso Technical Review, 9-2 (2004) 88-94.

6) 小日向茂: “導電性接着剂,” 日本接着学会誌, 38-12 (2002) 485-492.

7) 豊瀬喜久郎: “自動車におけるアルミニウムの接合について”, 日 本接着学会誌, 34-11 (1998) 439-445.

8) 川上博士: “大気中におけるアルミニウムの接合に関する一検 討,” 溶接学会誌, 73-4 (2004) 246-249.

9) 武田修: "高熱伝導性導電接着剤の開発と応用," 第59回マイクロ 接合研究委員会 (1999) 73-80.

10) 寺田信人, 松葉頼重: "はんだ代替銀ペーストの開発," Mate2006, 12 (2006) 59-62. 